\title{
Testeos bidireccionales de material pedagógico. Una experiencia con estudiantes de E/LE (Español como Lengua Extranjera)
}

\author{
Graciela Brengio de Cimino (1), Ana Copes ${ }^{(2)}$
}

\section{Palabras clave:}

transposiciones didácticas · testeos · reescrituras . interculturalidad · estudiantes de E/LE

Resumen. Testear material pedagógico es un acto complejo, más aún cuando está destinado a estudiantes de lenguas extranjeras, en este caso, de E/LE (Español como Lengua Extranjera). La experiencia refiere a los testeos correspondientes a Pistas de Lectura. Veinte textos breves de santafesinos con actividades para estudiantes de $E / L E$, que incluye un libro, un cuadernillo con claves de respuestas y un CD audio, publicados por Ediciones UNL en octubre de 2010.

La tarea excedió ese objetivo y derivó en nuevas perspectivas que se organizan en dos dimensiones: una primera instancia relacionada con el estudiante y el material, y otra con la mirada reflexiva de las autoras sobre las devoluciones.

Esa doble dimensión tiene algunas particularidades: los estudiantes testeados resuelven actividades y vuelven críticamente sobre ellas desde el horizonte de su propia cultura y así las evalúan. Las autoras no sólo modifican la formulación inicial y las sucesivas reescrituras sino que también aprenden a partir de las miradas multiculturales de los testeados.

(1 - 2) Facultad de Humanidades y Ciencias, UNL.

\author{
Keywords: \\ didactic transpositions - testing - rewrites · \\ interculturality $\cdot \mathrm{E} / \mathrm{LE}$ (Spanish as a Foreing \\ Language) students
}

Abstract. Testing teaching material is a complex act, especially when this material is intended for foreign language students, in this case, E/LE (Spanish as a Foreign Language) students. The present work reports on the testing of Pistas de Lectura. Veinte textos breves de santafesinos con actividades para estudiantes de $E / L E$, which includes a book, a booklet with answer keys and an audio CD, published by Ediciones UNL in October 2010.

The task, originally aimed at making some adjustments to the proposal, exceeded that goal and led to new perspectives, which for the sake of clarity, are organized in two dimensions: a first instance in relation to the students and the material, and the other concerning the authors' thoughtful look at the students' responses.

This double dimension has some peculiarities: tested students solve activities, respond to them critically and assess them within the horizon of their own culture. The writers not only modify the initial writing and their subsequent rewrites, but also learn from the multicultural perspectives of the tested students - from occidental and oriental cultures-. This experience enriched the original proposal by facilitating the observation of the material from other angles. 